\title{
Towards an Era of Peace and Common Prosperity in Northeast Asia
}

\author{
Secretary-General SHIN Bong-kil \\ Trilateral Cooperation Secretariat
}

First of all, I would like to extend my sincere gratitude to the Center for Economic Integration at Sejong University and the Hanns Seidel Foundation Korea for inviting me to take part in this conference. Also, my special thanks go to Mr. PARK Woo-Hee, the President of Sejong University. I am all the more grateful and honored that today's conference has been convened to celebrate and promote the mission and vision of the Trilateral Cooperation Secretariat.

\section{Background}

Trilateral cooperation goes back 12 years ago, when the leaders of the three countries had an informal breakfast meeting on the occasion of the ASEAN+3 in November 1999. This was the first meeting among the heads of governments of these three countries in modern times. Considering the historic and geographic proximity, such meeting was certainly long overdue, to say the least.

Since then, the three countries have made some significant progress in strengthening their cooperation. For example, rather than meeting on the sidelines of ASEAN+3 summits they have started to hold independent trilateral summit meetings, starting in 2008. In 2009, the President Lee Myung-bak proposed to set up a permanent Secretariat for the implementation of effective and systematic management of trilateral cooperation during the second trilateral summit meeting.

On the occasion of the third Trilateral Summit, the agreement on the establishment of the Trilateral Cooperation Secretariat was adopted and thus, the consensus to set up a permanent secretariat in Seoul was finally reached among the three countries.

\footnotetext{
*Corresponding address: SHIN Bong-kil; Secretary-General at Trilateral Cooperation Secretariat, Ministry of Foreign Affairs and Trade, 60, Sajik-ro 8-gil, Jongno-Gu, Seoul 110-787, Republic of Korea, TEL: +82-2-2100-2114, FAX: +82-2-2100-7999 E-mail: shinbk @yahoo.com (C)2012-Center for Economic Integration, Sejong Institution, Sejong University, All Rights Reserved.
} 
Upon the agreement signed and ratified by each of the three parties in 2010, the Trilateral Cooperation Secretariat was officially launched in Seoul, September 2011.

\section{A New Era of Northeast Asian Cooperation: Significance of the Establishment of the Trilateral Cooperation Secretariat}

Even though the presence of a permanent cooperative body itself can hold much importance, especially in the area where cooperation has been considered unrealistic, I would like to further emphasize on the significance that the establishment of the Secretariat holds beyond its symbolic meaning:

First, the establishment of a permanent secretariat represents the first constructive effort to institutionalize trilateral cooperation among Korea, China and Japan. Upon the establishment of the Secretariat, it is expected that the three states will strengthen their cooperation in a wider range of areas by fostering the existing cooperative mechanisms and further systemizing them. Jean Monnet, the founder of European Union has also underlined that sustainability of the cooperation is largely dependent upon institutionalization efforts. In essence, institutionalizing the existing cooperation among the three states represents a big step towards systematic and efficient management of the cooperation.

Second, the Secretariat allows the three countries to cooperate on equal terms. The three member states take an equal share of the Secretariat's activities and contribute equal shares to its budget. The Secretary-General is also appointed on a rotational basis in the order of Korea, Japan and China with two-year tenure of office. Each party other than the Government of the country of the SecretaryGeneral shall nominate a Deputy Secretary-General respectively. The General Services Staff members of the Secretariat are also recruited from all three countries, each sharing $1 / 3$ of the total numbers.

Third, the Secretariat exhibits political will and solidarity to bring peace and prosperity to Northeast Asia. As you know, much of our history reveals that the most frequent meetings or encounters among the three states took place during the war. The fact that the leaders of the three governments and legislative bodies agreed to establish the Secretariat conveys powerful, forward-looking political message that three countries are willing to overcome past rivalries and tensions, and pursue common prosperity and peace.

Fourth, the member countries of the Secretariat are composed of top-tier economic 
powers. As a group of top economic powers ranked at $2^{\text {nd }}, 3^{\text {rd }}$ and $13^{\text {th }}$ respectively, in terms of GDP, the total of the three accounts for $20 \%$ of the World's GDP, which creates the $3^{\text {rd }}$ largest economic block following NAFTA and EU. Also, their combined population makes up almost $25 \%$ of the world population.

Fifth, the launch of the Secretariat can contribute to consolidating regional cooperation. Compared to other regions, there has not been any substantial effort to institutionalize cooperation in Northeast Asia. Trilateral Cooperation Secretariat, in the long term perspective, is expected to reverse this trend and lay a concrete foundation for East Asian Community building. We should note that the EU, one of the successful regional organizations, also began as a small body called European Coal and Steel Community (ECSC) and took several decades to achieve the current status.

\section{Current Status of Trilateral Cooperation and its Future Agenda}

There are over 50 consultative mechanisms and 100 cooperative projects among the three countries. At the upper level, we have the Trilateral Summit Meeting and 17 Ministerial Meetings. The lower-level channels include Director-General and Working level meetings. In addition to these mechanisms, cooperative projects that have been discussed among the three states are well manifested in 'Vision 2020', a declaration adopted by the three leaders. 'Vision 2020' covers a wide range of agenda from economic cooperation like trilateral Free Trade Agreement, to diplomatic issues like cooperation on anti-terrorism.

Our Secretariat will work further to support the implementation of these cooperative projects, especially in the area of disaster relief and nuclear safety that has been highlighted after the Fukushima incident alongside with trilateral Free Trade Agreement, CAMPUS Asia program and cultural exchanges among the young.

\section{Past and Future of Northeast Asian Integration: Feasibility}

Now let me move on to discuss Northeast Asian regional integration in depth. First of all, I would like to note that we already had a distinguished pioneer in this area, even a century ago, who envisioned Northeast Asian peace and common prosperity through regional integration. His name is Ahn Joong Geun, a renowned Korean patriot in the early $20^{\text {th }}$ Century. 
Ahn insisted on turning LuShun, which served as a fierce battlefield among Japan, China and Russia during the Sino-Japanese and the Russo-Japanese War, into a neutral zone. There, he pursued the establishment of a permanent peace mechanism consisted of delegations from the three states, China, Japan and Korea. Moreover, he claimed that the three states should form a common military force, share a common currency unit, and build a collaborative university to teach young generation a value of peace and prosperity. He added that this is the only way to avoid the reoccurrence of war and to achieve common prosperity in the region. It comes as a surprise to find out that the ideas which generated EU integration were already initiated by a Korean, more than a half-century ago.

A number of scholars majoring in European integration are, however, still quite pessimistic on the possibility of Northeast Asian regional integration arguing that European experience is much different from Northeast Asian region. For instance, at the 2011 Asia Economic Community Forum held in Songdo, Incheon City where I participated as a panelist, majority of scholars presented their negative prospects on the potentials of Northeast Asian regional integration. They claimed that Northeast Asian countries have less commonality and relatively weaker political will, compared to European counterparts. They also said that this maybe attributable to the absence of visionary leaders like 'Jean Monnet' who is known as 'The Father of Europe'.

I must say that there is partial truth in what they said. European integration came to happen with an urgent need to avoid another war in the region, with France and Germany in the forefront to take control of the war resources such as coal and steel. On the other hand, post WWII Northeast Asia was largely divided into two camps led by the Soviet Union and the United States: Communist bloc and Western bloc. In other words, unlike France and Germany, Northeast Asia had immediately entered another era of conflict before getting a chance to reconcile. Simply speaking, Northeast Asia and Europe have different starting conditions.

Nevertheless, Northeast Asia has been through a dramatic change in the recent years. With China's rapid transition to market economy, this region has become the world's most dynamic area, especially in terms of economy, in the past several decades. As I mentioned earlier, China, Japan and Korea now take the $2^{\text {nd }}, 3^{\text {rd }}$ and $13^{\text {th }}$ place respectively, in terms of GDP, and interdependence among the three countries have also deepened in the areas such as people-to-people exchanges, cultural exchanges, trade, and investment. This tendency raises the possibility of regional integration and mutual cooperation among the Northeast Asian countries. 
It is also true that relatively stable situation has been maintained in Northeast Asia for the past few decades. However, territorial disputes and burst of nationalism in these countries may lead this region into political instability. Economic integration of Northeast Asia is thus very important in terms of reducing chances of hostile exchanges.

\section{The Trilateral FTA-Economic Cooperation for Co-prosperity}

People usually introduce Free Trade Agreement (FTA) as the first step towards economic integration. As you may already know, recently there have been a lot of discussions on FTA in Northeast Asia. As for the Trilateral FTA, two years of joint study among industries, government officials, and academia after seven years of joint study within private sectors is scheduled to conclude by the end of this year. If the three parties have political will, I expect a full-fledged negotiation to start from the next year.

The bilateral or trilateral FTA that is discussed among the three parties can gain impetus since the ratification of Korea-U.S. FTA and the decision by the Japanese government to participate in TPP (Trans-Pacific Partnership) negotiation. The TPP is a multilateral free trade agreement that aims to draw in ten trans-pacific countries such as U.S. and Japan. Besides removing tariff barriers, it aims to remove non-tariff barriers in copyright, labor regulation, finance, and medical practice.

The decision made by Japanese Prime Minister Yoshihiko Noda to participate in TPP negotiation can be seen as a political declaration that the Japanese government will not be swung around by the agricultural sector, the Japan's biggest obstacle in FTA negotiations with Korea and China. Although there is a lot of skepticism in feasibility, the decision itself, at least, is a big change that could never have been imagined in the past.

I believe that a great change would take place in economic integration of Northeast Asia. For the past few years, the biggest problem in FTA negotiation was a lack of political will in each country. However, after the earthquake on March 11, Japan, one of the major participants, has been going through a substantial change. It seems that desperate sense of crisis caused Japan to go through such change.

I also believe that intense economic integration would further boost political cooperation in Northeast Asia. The EU strove for economic integration after setting the first political goal-prevention of another war. In Northeast Asia, change is 
taking place in the opposite direction. I would like to note that I am using the term "cooperation" instead of "integration", because it is too early to refer to "integration" in current situation in Northeast Asia.

\section{Future of Regional Integration-Integration of Heart}

The biggest obstacle in this region in terms of cooperation and integration is the issue of overcoming unfortunate past and moving toward true peace. In other words, it is the issue of attitudes of the related parties opening up their heart and making serious efforts to achieve peace and cooperation. It has been only 20 yearsless than 20 years-since the three countries moved out of the Cold War system. Next year, the year 2012, is the $20^{\text {th }}$ anniversary - just $20^{\text {th }}$ anniversary - of establishment of diplomatic relations between the People's Republic of China, and the Republic of Korea. It would, therefore, take us more patience to witness peace and co-prosperity in Northeast Asian region.

The second issue is North Korea. In order to solve North Korean issue, we, the three countries should put more efforts to open up North Korea and engage the country in a more open economy. The construction of gas pipeline that would connect the Korean Peninsula, China, and Russia may also contribute to economic integration of this region. This can be utilized as one of the methods for aids to North Korea.

Fundamentally speaking, if we strengthen cooperation and integration in Northeast Asia for peace and co-prosperity, it will play a decisive role in resolving North Korean issues and in the integration of the Korean Peninsula.

Lastly, I would like to mention that integration does not necessarily mean achievement of a single market and currency under a single flag. What is more important is integration of heart and mind for mutual respect and understanding; and this is what Northeast Asia needs at current stage. Thank you. 